\title{
Choroidal neovascularization associated with sympathetic ophthalmia: case report
}

\author{
Neovascularizaçãocoroidiana associada à oftalmia simpá tica:relatodecaso
}

\author{
Raul Nunes Galvarro Vianna ${ }^{1}$ \\ Pinar Özdal ${ }^{2}$ \\ João Pessoa Souza Filho ${ }^{3}$ \\ Jean Deschênes ${ }^{4}$
}

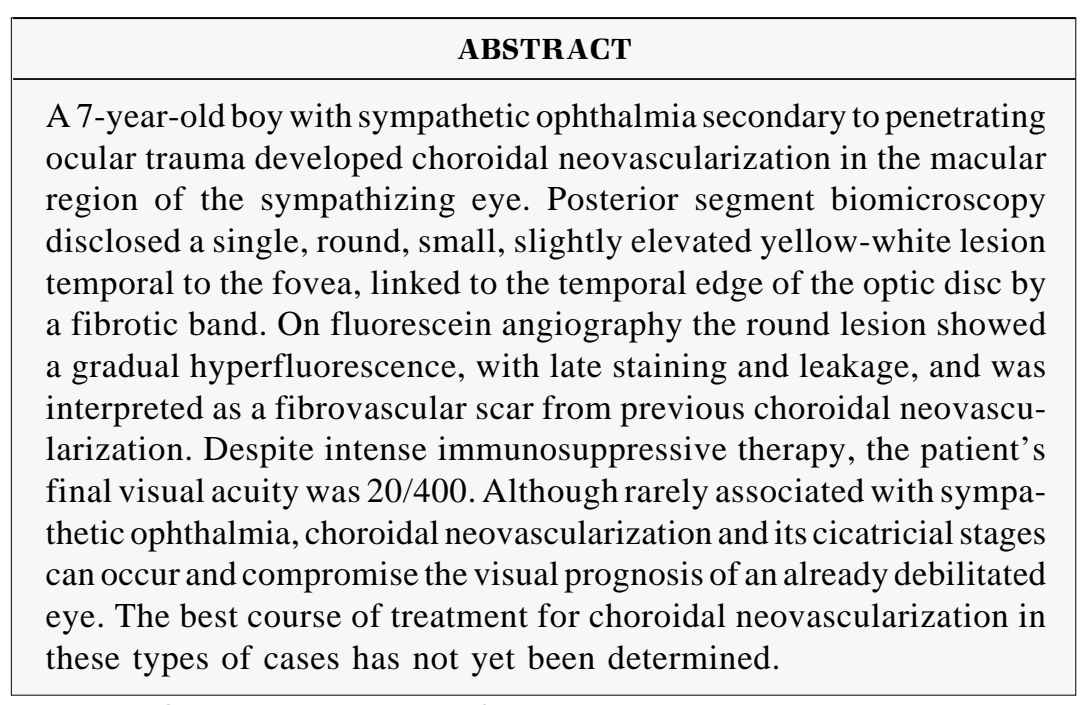

Keywords: Ophthalmia, sympathetic; Choroidal neovascularization, Immunosuppressive agents; Wound healing
Trabalho realizado no Setor de Uveites, Departamento de Oftalmologia Royal Victoria Hospital, McGill University Health Center, Montreal, Quebec, Canada.

${ }^{1}$ Post-Doctorate Fellow, Uveitis and Ocular Immunology Service, Royal Victoria Hospital, McGill University, Montreal, Canada. Post-Doctorate Fellow, The Henry C. Witelson Laboratory of Ocular Pathology and Oncology, McGill University, Montreal, Canada. Associate Professor of Ophthalmology, Head Retina and Vitreous Unit, Fluminense Federal University. Niterói (RJ) Brazil.

${ }^{2}$ Post-Doctorate Fellow, The Henry C. Witelson Laboratory of Ocular Pathology and Oncology, McGill University, Montreal, Canada.

${ }^{3}$ Doctorate-Fellow, Department of Ocular Pathology, McGill University, Montreal, Canada. Staff-member, Department of Ophthalmology, Jundiaí Medical School. Jundiaí (SP), Brazil.

${ }^{4}$ Professor, Department of Ophthalmology, McGill University Health Center, Montreal, Quebec, Canada.

Address to correspondence: Raul Nunes Galvarro Vianna, MD, PhD. Av. Ary Parreiras, 438 - Niterói (RJ) CEP 24230-322 - Brazil

E-mail: raulngvianna@ig.com.br

Recebido para publicação em 07.12.2003

Versão revisada recebida em 31.01.2005

Aprovação em 04.03.2005

\section{INTRODUCTION}

Sympathetic ophthalmia (SO) is a diffuse granulomatous uveitis occurring in patients who have sustained a previous penetrating ocular injury either as a result of trauma, or, rarely as a consequence of ocular surgery ${ }^{(1)}$.

Choroidal neovascularization (CNV) is a common clinical manifestation associated with numerous diseases that affect the posterior segment. Essentially any pathologic process that disturbs the retinal pigment epithelium (RPE) and Bruch's membrane can result in $\mathrm{CNV}^{(2)}$. However, $\mathrm{CNV}$ is usually accompanied by fibrous tissue. Often, over time, this fibrovascular tissue destroys the plane of the RPE, so the location of the CNV with respect to the RPE can no longer be readily identified ${ }^{(2)}$. When located in the macula, this pathologic process often leads to severe visual loss.

In this paper we report a patient with SO secondary to penetrating ocular trauma who developed CNV and, subsequently, a fibrovascular scar in the macular region of the sympathizing eye. CNV associated with SO has rarely been described and, in our case, definitively compromised the patient's visual acuity $(\mathrm{VA})^{(3-8)}$.

\section{CASE REPORT}

A 7-year-old boy had a sharp trauma to his right eye, which resulted in corneal laceration, uveal prolapse and traumatic cataract. His VA was light 
perception in the right eye and 20/30 in the left eye. The patient developed SO 45 days following the repair of the wound. Enucleation of the right (exciting) eye was completed 8 days after the diagnosis of SO, in the patient's hometown. It was at this point that the patient came to be evaluated in our Uveitis Clinic. His corrected VA was $20 / 30$ in the left eye. Slitlamp examination of the anterior and posterior segments revealed mutton fat keratic precipitates, +2 cells in the anterior chamber, +2 vitreous cells, and some confluent patches of yellow-white choroidal infiltrates. The inflammation in this eye was initially controlled with topical and systemic corticos- teroids (oral prednisone, $50 \mathrm{mg} /$ day). However, after four months the inflammation increased and the patient's VA dropped to $20 / 80$. Cyclosporine (100 $\mathrm{mg} /$ day) was then added to the therapeutic scheme, and the inflammation eventually became controlled. The patient was able to taper and discontinue oral prednisone within six months, but he continued with cyclosporine therapy (100 mg/day). However, after three years of follow-up the patient's VA dropped to 20/200 secondary to a posterior subcapsular cataract. At this period, the fundus details could not be evaluated. The decision to operate was reached one year following the cataract diagnosis. Phaco-

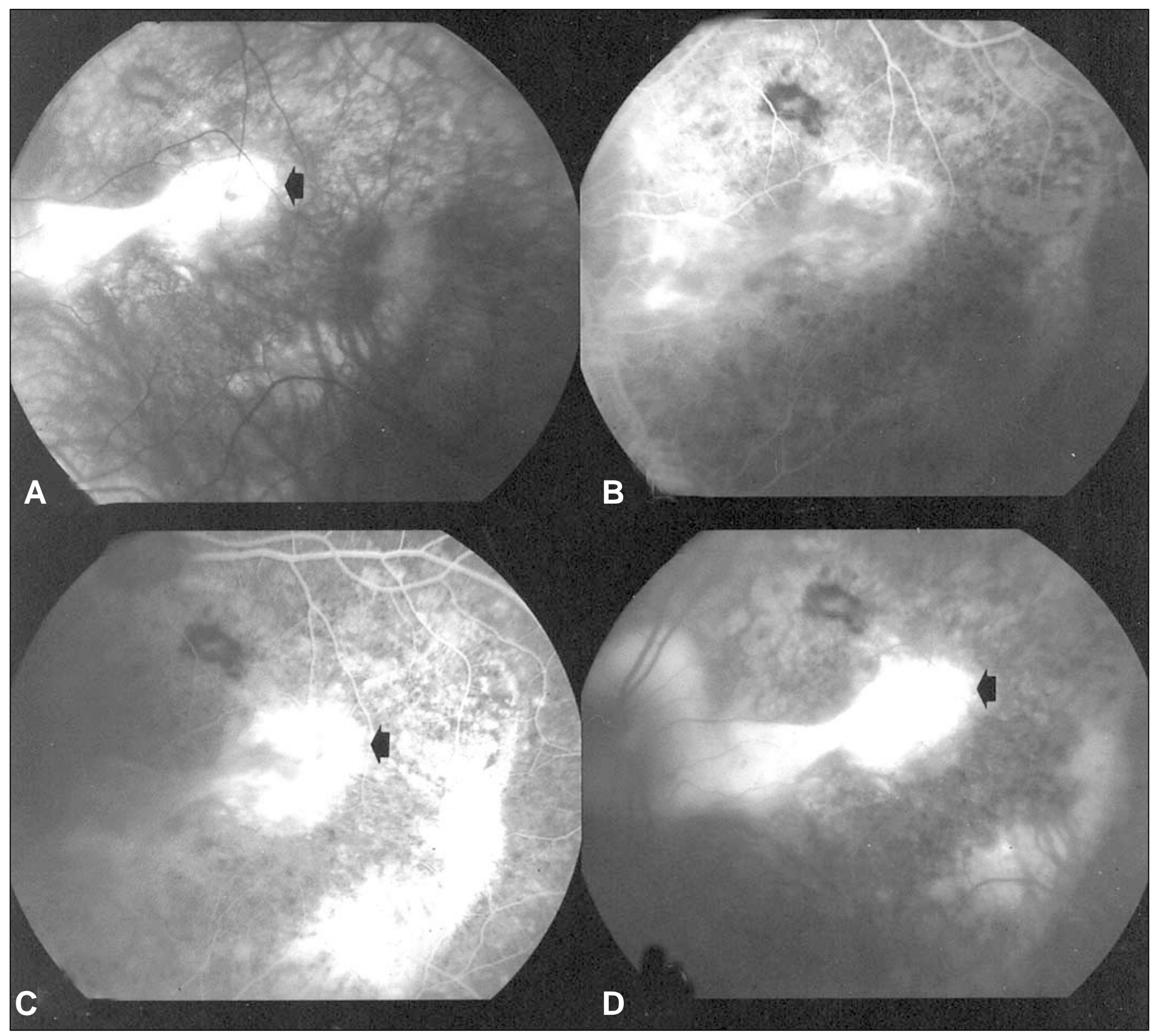

Figure 1 - A: Red-free fundus photograph revealing the small, round, whitish disciform lesion (arrow) linked to the temporal edge of the optic disc by a fibrotic tissue; B, C and D: Fluorescein angiography reveals progressive fluorescence with late staining and leakage of the disciform lesion (arrow), consistent with the diagnosis of fibrovascular scar from previous CNV 
emulsification with an in-the-bag posterior chamber lens implantation was successfully performed and the patient's vision improved to 20/40. Ophthalmoscopy at that time showed a diffusely depigmented fundus, as well as Dallen-Fuchs spots in the macular region. However, six months post-surgery, his VA dropped to 20/200. Ophthalmoscopy then revealed a small, round, slightly elevated whitish lesion temporal to the foveal region, which was linked by a fibrotic band to the edge of the optic disc (Figure 1A). Fluorescein angiography showed a gradual hyperfluorescence of the round lesion, with late staining and leakage (Figure 1B, C and D). This was interpreted as fibrovascular tissue in the subretinal layer from previous choroidal neovascularization. Given the advanced cicatricial stage of the process, no treatment was proposed.

The patient was followed up regularly. When last seen, he was on cyclosporine ( $150 \mathrm{mg} /$ day $)$, azathioprine $(75 \mathrm{mg} /$ day $)$ and prednisone ( $30 \mathrm{mg} /$ day), the ocular inflammation was controlled, but his VA was 20/400.

\section{DISCUSSION}

The pathogenesis of SO is unknown. Light and electron microscopic studies in eyes with SO have shown breaks in Bruch's membrane ${ }^{(9)}$. Discontinuities in Bruch's membrane are likely secondary to the inflammatory nature of SO and presumably allow for CNV to develop. Moreover, it has been demonstrated that CNV may arise from Dalen-Fuchs nodules, which correspond to granulomas composed of a mixture of histiocytic cells, depigmented pigment epithelial cells, and a few scattered T lymphocytes, located between Bruch's membrane and an attenuated covering of $\mathrm{RPE}^{(1)}$. These nodules may also cause an interruption of Bruch's membrane, thus leading to CNV. Sharp et al. showed that the histopathological changes surrounding these nodules consisted of obliteration of the underlying choriocapillaries with multiple breaks in Bruch's membrane ${ }^{(10)}$.

CNV has been reported in approximately $10 \%$ of patients with Vogt-Koyanagi-Harada (VKH) syndrome, a disease with clinical and histopathological features similar to $\mathrm{SO}^{(11)}$. $\mathrm{CNV}$ in $\mathrm{VKH}$ syndrome is reported more commonly in eyes with severe inflammation, greater pigmentary disturbance in the retina, and more frequent relapses. All these clinical and ophthalmoscopic features were seen in our patient.

To the best of our knowledge, six patients with SO and $\mathrm{CNV}$ have been reported to date $\mathrm{e}^{(3-8)}$. Table I summarizes the clinical features of previously reported patients, and also includes the data of our case.

The first report was on a 4-year-old boy who developed SO three months following a sharp ocular trauma ${ }^{(3)}$. The patient developed a CNV in the sympathizing eye that regressed spontaneously, and the final VA was 20/30. A second case of CNV in $\mathrm{SO}$ was reported in a 16-year-old $\operatorname{gir} \mathrm{l}^{(4)}$. She developed a posterior subcapsular cataract in the sympathizing eye during the evolution of SO. The patient then underwent a pars plana lensectomy and vitrectomy, following this procedure a subfoveal CNV was detected. Her final VA was 20/200, but the authors did not mention any specific treatment for the CNV. In a third patient with $\mathrm{SO}$ and $\mathrm{CNV}$, cyclosporine induced the resolution of the $\mathrm{CNV}^{(5)}$. The final VA in this particular case (a three-year-old boy) was 20/30. In the fourth reported case, laser photocoagulation was successfully used to destroy the CNV in a 41-year-old man with $\mathrm{SO}^{(6)}$. Four years after laser treatment, his VA was 20/25 with no evidence of recurrence of CNV. In the fifth case, a 55-year-old male developed SO after pars plana vitrectomy in the fellow eye ${ }^{(7)}$. SO has been succesfully treated with corticosteroids, cyclosphosphamide and cyclosporine. However, within one year the patient developed choroidal neovascularization in the sympathizing eye. Unfortunately, the author did not give details about the visual outcome of the patient. In the sixth case, a 60-year-old man with $\mathrm{SO}$, the CNV was surgically removed ${ }^{(8)}$. His final VA was approximately 20/100. In fact, unlike the CNV seen in age-related macular degeneration, in which the neovascular membrane develops in the subpigment epithelial space (type $1 \mathrm{CNV}$ ), the CNV associated with SO is likely located in the plane anterior to the RPE (type $2 \mathrm{CNV})^{(12)}$. Successful surgical results have been reported in patients with this latter type of membrane ${ }^{(13)}$.

Our 7-year-old boy with SO developed a fibrovascular scar from previous $\mathrm{CNV}$ located in the macular region, which led to a final VA of 20/400. Due to the severe inflammation, our patient has been on immunosuppressive drugs during most of his treatment. We do not know if these agents played any role

\begin{tabular}{|c|c|c|c|c|c|}
\hline Reports & Sex & $\begin{array}{c}\text { Age } \\
\text { (years) }\end{array}$ & $\begin{array}{l}\text { VA when CNV was detected } \\
\text { in the sympathizing eye }\end{array}$ & $\begin{array}{l}\text { CNV specific } \\
\text { treatment }\end{array}$ & Final VA \\
\hline Chew \& Crawford(3) & $\mathrm{M}$ & 4 & $20 / 100$ & No & $20 / 100$ \\
\hline Carney et al. ${ }^{(4)}$ & $\mathrm{F}$ & 16 & Not determined & No & $20 / 200$ \\
\hline Kilmartin et al. ${ }^{(5)}$ & $M$ & 3 & $20 / 30$ & Cyclosporine & $20 / 30$ \\
\hline Borkowski et al. ${ }^{(6)}$ & M & 41 & $20 / 60$ & Photocoagulation & $20 / 25$ \\
\hline $\mathrm{Frau}^{(7)}$ & M & 55 & Not mentioned & Not mentioned & Not mentioned \\
\hline Bom et al. ${ }^{(8)}$ & M & 60 & $20 / 200$ & Surgical removal & $20 / 100$ \\
\hline Vianna et al. & M & 7 & $20 / 200$ & $\begin{array}{l}\text { Cyclosporine and } \\
\text { azathioprine }\end{array}$ & $20 / 400$ \\
\hline
\end{tabular}


in the clinical course of the CNV. Interestingly, it has been observed that immunosuppressive therapy may decrease the incidence of choroidal neovascularization in inflamed eyes ${ }^{(14)}$. Some authors have successfully used these drugs to treat $\mathrm{CNV}$ associated with endogenous posterior uveitis ${ }^{(5,14)}$. Whether immunosuppressive agents decrease the rate or cause involution of $\mathrm{CNV}$ in $\mathrm{SO}$ is unclear. Because this is a rare association, a randomized and prospective study of $\mathrm{CNV}$ treatment in SO would probably not be feasible.

The value of immunosuppressive agents, laser photocoagulation or surgical resection in the treatment of $\mathrm{CNV}$ in eyes with SO is unknown, since the neovascularization in these cases can resolve spontaneously. Factors such as the young age of some affected patients and the small area of involvement by the CNV may be important in this spontaneous regression.

We conclude that although rarely associated with SO, $\mathrm{CNV}$ can be a catastrophic complication in an already debilitated eye. To date, the best option for treatment of CNV in these cases has not yet been determined.

\section{ACKNOWLEDGMENT}

We would like to thank Ms. Janet B. Scullion and Mr. Stephen Riopel for helping with the editing of the manuscript.

\section{RESUMO}

Paciente com oftalmia simpática (OS) desenvolveu neovascularização coroidiana (NVC) na região macular do olho simpatizado. A biomicroscopia do segmento posterior do olho afetado revelou uma pequena lesão branco-amarelada, discretamente elevada, localizada na região temporal à fóvea. Uma banda fibrosa ligava o disco óptico à lesão foveal. À angiografia fluoresceínica, a lesão revelou hiperfluorescência progressiva, com impregnação e extravazamento tardio do corante, achados esses característicos de uma cicatriz fibrovascular. Apesar de intenso tratamento com medicação imunossupres- sora, a acuidade visual final do paciente foi de 20/400. Embora raramente associada à oftalmia simpática a neovascularização coroidiana pode ocorrer e comprometer o prognóstico visual de um olho já debilitado. A melhor opção para o tratamento da neovascularização coroidiana em casos de oftalmia simpática ainda não está determinada.

Descritores: Oftalmia simpática; Neovascularização coroidal; Drogas imunossupressoras; Cicatrização de feridas

\section{REFERENCES}

1. Rao N. Sympathetic ophthalmia. In: Ryan SJ, editor. Retina. St Louis, MO: Mosby; 2001. p.1756-61.

2. Ryan SJ, Hinton DR, Murata T. Choroidal neovascularization. In: Ryan SJ, editor. Retina. St. Louis, MO: Mosby; 2001. p.1003-23.

3. Chew EY, Crawford J. Sympathetic ophthalmia and choroidal neovascularization. Case report. Arch Ophthalmol. 1988;106(11):1507-8.

4. Carney MD, Tessler HH, Peyman GA, Goldberg MF, Williams DP. Sympathetic ophthalmia and subretinal neovascularization. Ann Ophthalmol. 1990; 22(5):184-6.

5. Kilmartin DJ, Forrester JV, Dick AD. Cyclosporine-induced resolution of choroidal neovascularization associated with sympathetic ophthalmia. Arch Ophthalmol. 1998;116(2):249-50.

6. Borkowski LM, Weinberg DV, Delany CM, Milsow L. Laser photocoagulation for choroidal neovascularization associated with sympathetic ophthalmia. Am J Ophthalmol. 2001;132(4):585-7.

7. Frau E. [Sympathetic ophthalmia complicated by subretinal neovascularization]. J Fr Ophtalmol. 2001;24(6):672-3.French.

8. Bom S, Young SF, Gregor Z, Lightman S. Surgery for choroidal neovascularization in sympathetic ophthalmia. Retina. 2002;22(1):109-11.

9. Rao N, Xu S, Font RL. Sympathetic ophthalmia. An immunohistochemical study of epithelioid and giant cells. Ophthalmology. 1985;92(12):1660-2.

10. Sharp DC, Bell RA, Patterson E, Pinkerton MH. Sympathetic ophthalmia: histopathologic and fluorescein angiographic correlation. Arch Ophthalmol. 1984;102(2):232-5.

11. Moorthy RS, Chong LP, Smith RE, Rao NA. Subretinal neovascular membrane in Vogt-Koyanagi-Harada syndrome. Am J Ophthalmol. 1993;116(2):164-70.

12. Gass JD. Biomicroscopic and histopathologic considerations regarding the feasibility of surgical excision of subfoveal neovascular membranes. Am J Ophthalmol. 1994;118(3):285-98

13. Eckstein M, Wells JA, Aylward B, Gregor Z. Surgical removal of non-age related subfoveal choroidal neovascular membranes. Eye. 1998;12(Pt 5):775-80.

14. Dees C, Arnold JJ, Forrester JV, Dick AD. Immunosupressive treatment of choroidal neovascularization associated with endogenous posterior uveitis. Arch Ophthalmol. 1998;116(11):1456-61. 